\title{
Meeting the Health and Housing Needs of Plantation Workers $^{1}$
}

\section{Richard Laing and Marni Pigott}

\section{Introduction}

This article focuses on the health and housing needs of plantation workers in Malaysia, Sri Lanka, Zimbabwe and South India. In the first section, it identifies three general factors which constrain interventions intended to improve the health status and living conditions of plantation workers. In the second section, it suggests ways in which the living and working environment of plantations are interrelated and affect the incidence of disease and ill-health. In the third section, it illustrates the low health status of plantation workers in Malaysia, Sri Lanka and Zimbabwe. In the fourth section, it briefly assesses plantation health services in these three countries and in South India. With the exception of Malaysia, there are instances of successful health intervention which all share one characteristic. This is their formulation as part of a package of measures dealing with different but related aspects of the 'plantation environment'. The final section outlines a range of solutions to housing needs on plantations. These may be short or long term. However, the latter raise further issues of worker participation and 'home ownership' which implicitly lie at the heart of the poor working and living conditions found on many plantations. Plantation workers usually live in rent-free accommodation provided by their employers, and therefore have limited or no control over their 'space', either indoors or outdoors.

When discussing how best to improve the health status and living conditions of plantation workers through appropriate forms of development intervention, one should carefully consider the forms and limitations of such interventions. Three general observations can be made: first, the differential impact of structural change in plantations on plantation workers and their households. One particular feature of plantation production in many countries is the integration of more than one member of the household into the plantation system. The fact that several members are often employed from the same household provides employers with a rationale for paying low wages to plantation workers. This is often reinforced by the provision of 'free housing'. Conversely, a wage

1 For reasons of space, much of the statistical evidence presented at the workshop has been excluded by the editors. structure which assumes the participation of several members means that plantation households cannot rely on a single wage-earning member.

The way in which the household, as a unit of production, is integrated into the economic and social organisation of a plantation has many implications for how health and housing needs are defined. This will depend on a number of factors, for example: the size and composition of the household; the particular crop and the techniques involved in its production; and the scale and ownership of the plantation. In addition, it will be affected by the complex linkages between plantations and surrounding rural areas described by Davies in this Bulletin [see also Vaughan and Chipande 1986].

Second, changes in the composition of plantation labour. The tendency to employ a greater proportion of casual or temporary workers in the total plantation workforce has been noted in a large number of plantation settings [ILO 1985a; 1985b]. To the extent that employers assume responsibility for living conditions of workers employed, their primary concern is with the permanent workforce resident on plantations. However, the changing ratio between permanent and casual workers, or even an overall reduction in the demand for labour, is not necessarily reflected in a decrease in the population resident on plantations, particularly in those countries with a history of 'immigrant' or recruited plantation workers, such as Malaysia, Sri Lanka and India.

What effect does this have on health and living conditions on plantations? Declining yields in tea plantations in the Dooars district of West Bengal, for example, are reflected in the decrease in total employment over the period 1951 to 1980 . But the decrease in permanent workers has not meant a reduction in resident populations. Employment possibilities off the plantation for the plantation workforce, who mainly come from scheduled tribes, ${ }^{2}$ are limited; and declining possibilities within them have simply increased the ratio of dependency within plantation households of non-wage earning members to earners. The average population in a 'tea garden' is 4,000 , and there are 153 'gardens' in the district. In order to comply with the provisions of the 1951

\footnotetext{
${ }^{2}$ These are minority ethnic groups with legally defined territorial rights.
} 
Plantations Labour Act and the 1956 West Bengal Plantation Rules, more than 45,000 houses still had to be built in 1980. Moreover, over and beyond the provision of improved housing, the legislation dealt with sanitation, schools, medical facilities and other welfare measures such as creches. Yet, not a single 'garden' had complied with all the requirements of the legislation. In this type of 'labour surplus' situation, with increasing labour militancy coupled with the absence of any major rehabilitation programmes, intervention has taken the form of 'population control' programmes, through family planning and welfare [Prasanneswari 1984].

Nevertheless, there are numerous examples of initiatives in the sphere of health-related and housing activities which are clearly directed at attracting and keeping labour in situations where there are shortages of particular categories of plantation workers. Rubber tappers in parts of Peninsula Malaysia [Fan 1981], sisal cutters in Tanzania, and tea pluckers in some districts of Sri Lanka attracted from neighbouring Sinhalese villages [Gooneratne and Wesumperuma 1984] have all provided a focus for housing improvement programmes. Similarly, recent programmes for the rehabilitation of plantation production in many countries, which are geared towards increasing the productivity and efficiency of plantations through massive capital investment, include a social development component as in the example of the state-owned plantations in Sri Lanka [Sri Lanka 1984].

Third, the high proportion of female labour. In many plantation settings women comprise a large if not major section of the workforce. In Sri Lanka in 1977, for example, women workers constituted 51.1 per cent of the total workforce on tea, rubber and coconut plantations; and this ratio has been increasing [Sajhau 1985]. In India, the Tea Board's statistics for 1981-82 show that 56.03 per cent of the total labour-force for all India was composed of women and children [Paul 1984]. In Malaysia, over the period 1971 to 1980 when total employment in plantations declined (due to the shift from rubber to oil palm production which is less labour intensive), the participation of women in the recorded total labour force increased to 48 per cent. In rubber production in 1980, women workers comprised 55 per cent of the workforce [Navamukundan 1985]. It should also be noted that casual and seasonal workers include a high proportion of women [Vaughan and Chipande 1986; ILO 1985a; 1985b].

The linkage between the working and living environment of a plantation is particularly important in the case of women and when formulating health and housing needs on the basis of household tasks. Fetching water, organising domestic energy (for example, collecting firewood), maintaining standards of cleanliness, and preparing food are all carried out in addition to work in plantation production [Kurian 1982; Vaughan and Chipande 1986; Fan 1981; FAO 1984].

\section{Environmental factors and Health Status on Plantations}

The Infant Mortality Rate (IMR) provides the most important index of the overall health of a community. There are several other sensitive indicators, such as low birth weight, the incidence of anaemia, and neonatal death rate, which reflect community nutrition status. Many of the illnesses noted among plantation workers result from nutritional deficiencies, and the morbidity and mortality patterns in plantation communities are due largely to poor nutrition. But forms of ill-health which are among the principal causes of absenteeism, such as respiratory diseases, intestinal infections and diarrhoeal disease and the widespread incidence of anaemia typical of plantations [Paul 1984; Rahmathullah 1986; FAO 1984; Soekirman 1978] are also associated with non-nutritional factors. These relate to the living and working environment of plantations.

Environmental factors include the effects of poor environmental sanitation and inadequate supplies of safe water for health and personal hygiene, the effects of inadequate supplies of domestic energy for cooking, water and space heating, the effects of overcrowded and poorly ventilated dwellings and exposure to smoke. Women are particularly at risk due to their greater propensity for anaemia. Also, reduced birth weights and increased perinatal death rates have been associated with exposure to smoke from the combustion of biomass fuels. In addition, the range of respiratory diseases which affect all members of the household have been associated with exposure to smoke [WHO 1984]. Inflammatory reactions caused by recurrent exposure to irritant emissions, from the incomple te combustion in small open fires burning in poorly ventilated dwellings, make the trachea, bronchi and bronchioles susceptible to infection, especially in infants. Bronchitis has been found to be one of the major causes of the high child mortality rate on plantations in Sri Lanka and the incidence is much higher than in the rest of the country [FAO 1984].

Clearly, low levels of nutrition lessen resistance to diseases, the important point being that nutritional and non-nutritional environment factors are closely linked in the plantation setting. Take the example of anaemia, which is widespread among women plantation workers in India [Rahmathullah 1986], Sri Lanka [FAO 1984; SLSPC 1986], Sao Tome [ILO 1985a], and Indonesia [Soekirman 1978]. In addition to nutritional deficiencies, such as iron, folic acid and other vitamins, which are the major causes of nutritional anaemia, other factors such as frequent 
pregnancies and worm infestation are significant contributory causes. Hookworms are prevalent in damp soil or areas with defective sanitation since the eggs are transmitted in faeces. They can cause major blood loss when they establish themselves in the small intestine, and thus contribute to anaemia.

In the study of anaemia among plantation workers in Indonesia, which included men, women and children in the sample, as many as 85 per cent of the population studied suffered from hookworm infestation. The incidence of anaemia among women and children was double that found among the male plantation workers, which at 45 per cent was the highest rate ever recorded among males in non-famine conditions. Of the anaemic males, 60 per cent were found to have nutritional anaemia and, as Soekirman observes, income constraints play an important role, for plantation workers consume diets very low in calories and protein and belong to the lowest income group: 'The vicious circle of low income-inadequate foodmalnutrition and/or anaemia-low productivity-low income is likely to operate continuously in this group of people ... the only significant difference between anaemic and non-anaemic plantation workers is income level' [Soekirman 1978.146].

From the limited data available it would appear that patterns of morbidity on plantations vary during the year in relation to type of disease and incidence. These variation soccur both within and between plantations. In the case of Sri Lanka, where annual health returns of attendance at dispensaries on a number of different plantations were analysed, some important features are highlighted. Results show that respiratory diseases have the highest incidence in most plantations, followed by intestinal infections. Other significant reported reasons for attendance at dispensaries include anaemia, dengue, helminthiasia, scabies and other skin infections. Seasonal differences are very marked in some plantations and data from one low country tea estate indicate two morbidity peaks: one in June/July and one in November/December. The first peak in morbidity -was due mainly to intestinal infections. This is an annual occurrence when the first heavy rains sweep human faeces down the tea slopes (no latrines are provided in the areas cultivated under tea) to contaminate the water sources. As in most plantations, these consist of open wells, springs or streams. The second peak was due mainly to respiratory diseases associated with the cooler weather and the increased use of open fires in the dwellings [FAO 1984].

\section{The Health Status of Plantation Workers: Selected Examples}

In the following examples, which illustrate the health status of plantation workers in several countries, it should be remembered that the data simplify very complex relationships and interrelationships. The examples demonstrate the impact of nutritional and environmental factors; the complex linkage between the working and living environment within plantations; and the wider socio-economic context of plantation production and employment.

In Malaysia the ethnic composition of plantation labour has been changing. Since the mid-1960s, Malays have been encouraged to move into plantation employment, and their participation in the total workforce increased from 23 per cent in 1967 to 38 per cent in 1980. This was accompanied by a percentage reduction in the participation of Chinese, which decreased from 29 to 14 per cent over the same period. Indians, however, maintained their employment position at 48 per cent over the same period. The crude death rate of Indians is consistently higher than that of other ethnic groups [Malaysian Medical Association 1980]. Also, despite government policies towards the reduction of poverty, real wages have been falling and the incidence of poverty among plantation workers has increased during the last few years. Whereas in 1970 the percentage of plantation workers registered below the 'absolute poverty line' (based on nutrition) was 40.0 , by 1975 this had increased to 47 per cent. The percentage declined to 35.1 in 1980 , but by $1983 \mathrm{had}$ risen to 54.6 per cent [Jomo 1985]. It should be noted that the incidence of poverty is greater among rubber workers than oil palm workers and that it varies according to ownership [SERU 1981, 1983]. This poverty has been expressed in a high incidence of low birth weight, which is a sensitive indicator of community nutrition status [Kandiah 1982].

In Sri Lanka, which despite low per capita income has good national health status indicators [Gunatallike 1985], health conditions and health status indicators on plantations have been consistently below other rural areas on the island. The nutritional status of children within plantations is worse than in rural villages, although there has been an improvement over the last few years [Ministry of Health Sri Lanka 1976; Ministry of Planning Implementation 1982]. Low birth weight is common in Sri Lanka in general (27 per cent), but within plantations it exceeds 30 per cent. The fact that approximately 90 per cent of women are estimated to have anaemia clearly contributes to this, since one effect of low haemoglobins is low birth weights.

In Zimbabwe, detailed studies have been undertaken of the comparative nutritional status of children in different areas of the country. These studies show that the children of agricultural workers in the commercial farming areas have the worst nutritional status. In addition, low levels of immunisation coverage and inadequate access to health services have been documented [Chikanza 1981]. Table 1 indicates that 
Percentage with second and third degree malnutrition using NCHS standards for:

\begin{tabular}{|lccc|}
\hline & $\begin{array}{c}\text { Weight for age } \\
75 \% \text { of standard }\end{array}$ & $\begin{array}{c}\text { Weight for height } \\
80 \% \text { of standard }\end{array}$ & $\begin{array}{c}\text { Height for age } \\
90 \% \text { of standard }\end{array}$ \\
\hline Commercial farms & 40 & 15 & 30 \\
Peasant areas & 17 & 12 & 28 \\
Mines & 22 & 6 & 15 \\
Urban areas & 6 & 8 & 7 \\
\hline
\end{tabular}

Source: Loewenson 1986

children under five years living on commercial farms fare worse than children living in peasant areas, mines and urban areas on conventional child health standards.

\section{The Provision of Health Services on Plantations}

Within all plantations created by the British a similar system of health services developed. This was based on a plantation hospital and either a plantation medical officer or a visiting medical officer. Considerable efforts were made to reduce epidemic diseases, such as malaria, cholera and typhoid. But generally the medical services were curative and neglected health promotion or disease prevention [Mackay 1974; 1976]. Since Independence, there have been modifications.

In Malaysia, the overall structure inherited at Independence has persisted and a total of 65 hospitals cater for a population of 250,000 . There are on average eight beds to 1,000 population, but the bed occupancy rate is less than 30 per cent, assuming an average admission duration of seven days. Only five full-time doctors are employed, while 63 part-time doctors assist [Ministry of Health Malaysia 1980/81]. The hospitals are grossly underutilised and most plantation residents use government or private facilities off the estate [Laing 1986]. The Ministry of Health recognises the problem in its Annual Report of 1981 where it states that 'estate health services in general provide very poor quality of medical and health care and there is room for further improvement'.

In Sri Lanka, the traditional st ructure of hospitals and plantation medical officers persisted until nationalisation in the mid-1970s. During this time, infant mortality rates were more or less static at a level much higher than the comparative rate in villages. In 1974, during a period of severe food shortage, the IMR in plantations was three times the village rate [Meegama 1980; SLSPC 1986]. After nationalisation, health services were disrupted but in 1978 the Ministry of Health appointed medical officers to undertake maternal and child health clinics on estates. The nationalised state plantation agencies developed health and welfare development programmes and these were associated with a dramatic decline in infant mortality rates. Health interventions included construction or renovation of maternity units, dispensary building and equipment upgrading, staff training and support, emphasis on promotive and preventive services and the development of a health education programme based on 'line volunteers'. These community health workers met regularly with health staff; informed and educated estate residents; and acted at the local level to improve environmental hygiene. Programmes for improvements in water supply, housing, sanitation and creches have also contributed to a sustained improvement between 1982 and 1986, as illustrated in Table 2.

In South India there is a similar structure of medical services based on hospitals. It is supervised by the Ministry of Labour and the Ministry of Health. A detailed study of hospitals on plantations reported a $\mathrm{bed} /$ population ratio of 9.4 beds per 1000 , but the bed occupancy rate was only 35.7 per cent [Rahmathullah and Amar 1982]. Since the beginning of the 1970s, the United Planters' Association of South India [UPASI] have supported the development of an effective innovative health programme, the Comprehensive Labour Welfare Scheme (CLWS). With initial support from the Government for five years, the scheme involves CLWS staff working with estate medical staff in close collaboration with estate management [Rahmathullah 1982]. The scheme has included the training of 'link' or community health workers who disseminate health information and ensure community participation in health activities. Standardised health 


\begin{tabular}{|lccccc|}
\hline & 1982 & 1983 & 1984 & 1985 & $\%$ change \\
\hline Infant mortality rate per 1000 live births & 74 & 58 & 50 & 46 & $-37 \%$ \\
Stillbirth rate per 1000 live births & 67 & 62 & 55 & 51 & $-23 \%$ \\
Child mortality rate (age-specific) & 5.5 & 4.9 & 4.0 & 3.2 & $-41 \%$ \\
Perinatal mortality rate per 1000 live births & 99 & 89 & 78 & 75 & $-24 \%$ \\
$\begin{array}{l}\text { Neonatal mortality rate (deaths in 1st month) } \\
\quad \text { per 1000 live births }\end{array}$ & 46 & 36 & 32 & 34 & $-30 \%$ \\
$\begin{array}{l}\text { Post-neonatal mortality rate (after 1st month) } \\
\text { per 1000 live births }\end{array}$ & 28 & 22 & 18 & 12 & $-57 \%$ \\
Institutional births (\%) & 49 & 52 & 62 & 70 & $+42 \%$ \\
\hline
\end{tabular}

Source: SLSPC 1986

information reporting, advice on water and sanitation, improvement of creches, housing and an emphasis on preventive and promotive health activities have led to an improvement in health status indicators and the contraception rate [UPASI 1971-1984]. A further important consequence of the CLWS has been the saving on expenditure of sickness related benefits. However, participation in the CLWS is voluntary and, despite its success, only 40 per cent of UPASI members have participated. It would be useful to compare health indicators with those of non-CLWS UPASI estates and, indeed, with other plantation regions in India, such as West Bengal, since very wide disparities can be expected between tea 'gardens' in the Dooars district in West Bengal [Pigott 1986] and UPASI estates in South India.

In Zimbabwe an innovative programme has developed since Independence to provide primary health care to agricultural workers on large-scale commercial farms. The programme was based on the training of two farm health or community health workers from each farm community who, after training, were supported by a mobile support team. While curative services were provided, the emphasis was on health education and preventive and promotive activities. These included improved sanitation, water supplies, food production and child care. Evaluation of the programme's impact shows an improvement in nutritional status. Antenatal attendance, immunisation rates and other health indicators improved during the period of the programme and the initial pilot project is now being replicated in different areas of the country [Loewenson et al. 1983].

In summary, health interventions have been successful where they have been formulated as part of a package of measures dealing with different yet related aspects of the plantation environment.

\section{Housing: Solutions and Issues}

There already exist technical solutions to many of the problems in meeting 'basic needs' with regard to housing and related amenities. In most cases, these are low cost since the application of appropriate solutions does not necessarily imply prohibitive costs. The central issue is how to persuade those concerned of the importance of their implementation. However, this is a complex process which raises issues to do with the participation of plantation workers in decisions which affect their lives. Other wise, there is no guarantee that their needs will be reflected in improvement programmes.

There are two issues. On the one hand, there are interventions which can ameliorate overall conditions in the living environment and have an immediate measurable impact on the health status of plantation households. An improved (smoke-free) cooking environment, continuous water supply, individual latrines for each household, land for food production, and increased space available to the household are good examples. On the other hand, there are interventions which have long-term, more strategic objectives to increase effective participation, reduce dependency, delink access to housing from plantation employment, increase security of tenure and strengthen the social security of plantation workers and their households.

Interventions which address both issues (which are not mutually exclusive) can take a variety of forms, both at the sectoral level and at the level of the individual plantation or group of holdings. These include the provision of finance, subsidies or other incentives; housing 'funds' contributed to by employers and/or workers' organisations; and the formation of housing 
cooperatives, through savings schemes and/or building cooperatives. Interventions may originate with local or national authority policies and be integrated with rural development programmes. They may range from the provision of land, with or without services, to the provision of complete housing schemes and they may also involve new construction or the upgrading and rehabilitation of existing housing stock. The specific practices involved, and the variety of social contexts within which these different forms of intervention may occur, make generalisation problematic.

Many of the health-related problems confronting plantation workers arise from the fact that in 'rentfree' housing provided by management, households have limited or no control over their 'space', either indoors or outdoors. In most instances, 'traditional' plantation housing evolved on the basis of minimum standards. These came to be interpreted as the 'norm' and often consituted the only form of accommodation available. Examples of 'linerooms' are found in Sri Lanka, Malaysia and North and South India. The form is identical and based on the historically determined 'minimum' needs as defined in each context. Furthermore, because in 'rent free' accommodation, questions of maintenance and repair of dwellings are considered under consumption rather than productive investment, these tend to be the first items which are reduced when commodity prices fall.

It is against this background that the whole question of homeownership for plantation workers becomes especially important. However, ownership must not be confused with the notion of 'self-build', where plantation workers are expected and encouraged to build their own accommodation but where compensation is not necessarily agreed should they leave plantation employment. Various forms of 'self-build' housing are found on plantations, some more permanent than others [Laing 1986; Vaughan and Chipande 1986].

But none offer workers the same degree of security and quality of housing which they might reasonably expect under properly planned and implemented homeownership schemes. Such schemes would, of course, radically alter the sorts of choices faced by plantation workers in trying to improve the quality of their lives. Not least, homeownership would transform the basis for participation by workers in estate decision-making whether alongside or independently of management in matters pertaining to work and home respectively.

\section{References}

Chikanza, I. C., 1981, 'The health status of farm worker communities in Zimbabwe', Central African Journal of Medicine vol 27 no 5

Fan, N. H., 1981, "A preliminary study of women rubber estate workers in Peninsular Malaysia', Working Paper, ILO, Geneva
FAO, 1984, 'The food and nutrition situation of plantation women workers and their families', Nutrition Consultants Reports Series 68, Rome

Gooneratne, W. and D. Wesumperuma (eds.), 1984, Plantation Agriculture in Sri Lanka, ILO, ARTEP

Gunatallike, G., 1985, 'Health and development in Sri Lanka', in S. Halstead et al. (eds.), Good Health at Low Cost, Rockefeller Foundation

ILO, 1985a, 'The socio-economic implications of structural changes in plantations in African countries', Working Paper, Sectoral Activities Programme, Geneva

- 1985b, "The socio-economic implications of structural changes in plantations in Asian countries, Working Paper, Sectoral Activities Programme, Geneva

Jomo, K. S., 1985, 'Estates of poverty: Malaysian labour on rubber plantations', Publication 10, Malaysian Social Science Association

Kandiah, M., 1982, 'A review of the nutritional status of the Indian community in Peninsular Malaysia', The Family Practitioner vol 5 no 3, December

Kurian, R., 1982, Women Workers in the Sri Lanka Plantation Sector, ILO, Geneva

Laing, R. O., 1986, Health and Health Services for Plantation Workers, Evaluation and Planning Centre for Health Care, London School of Hygiene and Tropical Medicine, London

Loewenson, R., 1986, 'Farm labour in Zimbabwe: a comparative study in health status', Health Policy and Planning Vol 1 no 1

Loewenson, R. et al., 1983, 'The Bindura Farm Health Worker Scheme Interim Evaluation Report' and 'The health status of Farm Workers, An evaluation of the Bindura Project'

Mackay, D. M., 1974, 'Plantation medicine', Bangladesh Medical Journal, pp85-99, April

-1976, 'The plantation Medical Officer: his future role', Planters Chronicle LXXI, 10 October

Malaysian Medical Association, 1980, The Future of Health Services in Kuala Lumpur

Meegama, S. A., 1980, 'Socio economic determinants of infant and child mortality in Sri Lanka: an analysis of post-war experience', World Fertility Survey Scientific Reports Number 8, International Statistical Institute, Voorburg

Ministry of Health Malaysia, 1980/81, Annual Report, Kuala Lumpur

Ministry of Health Sri Lanka, 1976, Sri Lanka Nutrition Status Review, Office of Nutrition, USAID, Washington

Ministry of Planning Implementation, 1982, "Nutrition Status and Determinants, Food and Nutrition Planning Division, (mimeo)

Navamukundan, A., 1985, 'Structural change in the Malaysian plantation sector', in ILO, 1985b

Paul, A. P., 1984, Nutrition and Productivity in India, ILO, Geneva 
Pigott, M., 1986, 'Housing conditions and the provision of "basic needs" for plantation workers and their households", unpublished report for ILO

Prasanneswari, 1984, 'Industrial relations in tea plantations, the Dooars scene', Economic and Political Weekly, 16-23 June

Rahmathullah, V., 1986, 'Family welfare planning in South Indian plantations', UPASI

- and D. Amar, 1982, 'A study on utilisation of health services in South Indian plantations', UPASI

Sajhau, J. P., 1985, 'The socio-economic implications of structural changes in plantations: the case of Sri Lanka', in ILO, $1985 b$

SERU, 1981, Socio-economic Study of Rubber Estate Workers, Socio-Economic Research Unit, Government of Malaysia
-1983, Socio-economic Study of Oil Palm Estate Workers, Socio-Economic Research Unit, Government of Malaysia

SLSPC, 1986, Annual Report of Health Statistics, Colombo

Soekirman, 1978, 'Indonesia', in B. Winikoff (ed.), Nutrition and National Policy, MIT

Sri Lanka, 1984, Medium Term Investment Programme for the State Owned Plantations, 1985-89, Ministry of Finance and Planning, Colombo, June

UPASI, 1971-84, Statistical Returns 1971-84: CLWS Plantations, Niligris, Tamil Nadu

Vaughan, M. and G. Chipande, 1986, 'Women in the estate sector of Malawi: the tea and tobacco industries', Working Paper, ILO, Geneva

WHO, 1984, Biomass Fuel Combustion and Health, Geneva 